\title{
Pesan dari Editor
}

Para pembaca yang terhormat,

Jurnal Psikologi Sosial (JPS) telah mengalami beberapa kali perubahan sejak pertama kali terbit. Kini, memasuki tahun ke-3 setelah bekerja sama dengan Ikatan Psikologi Sosial, JPS mengalami perubahan lagi: perubahan situs web dan format jurnal. Dalam upaya memperbaiki standar dan mengikuti dinamika dunia akademik baik di Indonesia maupun di internasional, beberapa perubahan perlu dilakukan. Perubahan itu dilakukan dengan maksud untuk meningkatkan kualitas JPS.

Mulai dari edisi Volume 17 Nomor 1 2019, JPS menggunakan situs web baru. Penerbitan edisi ini sekaligus menjadi peluncuran situs web baru JPS. Situs web baru ini, selain berformat baru, memiliki sistem, struktur dan fitur lebih lengkap dari situs web terdahulu. Dengan perbaikan yang sudah dilakukan, kami berharap lebih memudahkan proses penerbitan artikel-artikel di JPS secara daring dan menambah kenyamanan pembaca untuk mengakses dan membacanya.

Format JPS berubah baik pada versi cetak maupun versi daring. Ada perubahan format halaman sampul dan perwajahan di halaman dalam JPS. Perubahan ini dilakukan untuk mempersegar penampilan JPS. Selain itu, logo JPS juga berubah disesuaikan dengan perubahan tata cara pembuatan dan penggunaan logo di UI. Semoga perubahan ini berdampak positif bagi JPS dan para pembaca.

Pada edisi Volume 17 Nomor 12019 ada enam artikel yang diterbitkan. Artikel pertama ditulis oleh Putra, Kusumawardhani, dan Narhetali (2019) melaporkan hasil intervensi sosial yang bertujuan untuk meningkatkan perilaku membaca remaja di Kabupaten Barru. Studi yang menggunakan metode eksperimental ini melaporkan hasilnya bahwa partisipan yang mendapatkan pesan visual nudge dengan pendekatan norm membaca lebih banyak dan lebih lama daripada partisipan dalam kelompok kontrol.

Artikel ke-2 ditulis oleh Hidayah dan Hariyadi (2019) tentang manajemen konflik di awal perkawinan, bertujuan untuk mengetahui perbedaan manajemen konflik suami-istri berdasarkan gender. Artikel ini melaporkan bahwa ada perbedaan kemampuan manajemen konflik antara perempuan dan laki-laki; perempuan memiliki kemampuan manajemen konflik perkawinan yang lebih baik daripada laki-laki.

Di artikel ke-3, yang ditulis oleh Widhyastuti dan Ariyanto (2019), dibahas hubungan antara kompetisi antar kelompok, identifikasi kolektif dan kesediaan anggota kelompok mengkritik ingroup (ingroup criticism). Artikel ini melaporkan hasil penelitian yang bertujuan untuk menguji peran kompetisi antar kelompok sebagai moderator pada hubungan antara identifikasi kolektif dan kesediaan anggota kelompok mengkritik ingroup. Hasilnya menunjukkan bahwa tidak ada interaksi yang signifikan antara identifikasi kolektif dan kompetisi antar kelompok dengan ingroup criticism tetapi ada pengaruh langsung yang signifikan dari baik identifikasi kolektif maupun kompetisi antar kelompok terhadap ingroup criticism.

Artikel ke-4, ditulis oleh Grasiaswaty, Widyartini, dan Siregar (2019), membahas hubungan antara nilai personal, nilai perilaku berbelanja, dan tendensi seseorang untuk membeli secara impulsif. Penelitian yang dilaporkan hasilnya di sini bertujuan menguji pengaruh nilai personal dan nilai perilaku berbelanja terhadap tendensi seseorang untuk membeli secara impulsif. Hasil penelitian ini menunjukkan, di antaranya, bahwa nilai berbelanja memprediksi tendensi pembelian impulsif, khususnya nilai hedonis.

Artikel ke-5 ditulis oleh Sahrani (2019) membahas mengenai faktor-faktor karakteristik kebijaksanaan pada remaja, khususnya pengukuran faktor-faktor itu. Artikel ini melaporkan penelitian yang bertujuan untuk mengembangkan skala kebijaksanaan pada remaja. Dari hasil penelitian ini diperoleh 44 butir karakteristik kebijaksanaan pada remaja yang dikelompokkan menjadi 3 faktor, yaitu faktor: (1) Berpikir Cerdas; (2) Kepribadian Positif; (3) Keterandalan dalam Bertindak.

Artikel ke-6 ditulis oleh Jamil, Gunarya, dan Kusmarini (2019) membahas mengenai ritual keluarga dan keberfungsian keluarga. Artikel ditulis berdasarkan penelitian yang bertujuan mengetahui kontribusi ritual keluarga dalam membedakan kadar keberfungsian keluarga berdasarkan persepsi anak yang berusia remaja. Hasilnya menyatakan bahwa hanya ada tiga setting ritual keluarga yang paling baik dalam membedakan kadar keberfungsian keluarga, yaitu liburan keluarga, waktu makan, dan tradisi budaya. Ada kontribusi ritual keluarga dalam membedakan tinggi-rendahnya keberfungsian keluarga.

Keenam artikel tersebut disajikan JPS baik dalam versi daring maupun versi cetak. Semua sudah melalui tinjauan mitra bestari dan Tim Editor JPS. JPS selalu berusaha menerbitkan artikel-artikel yang memadai dan memenuhi standar karya akademik di bidang psikologi sosial. Semoga artikel-artikel yang diterbitkan JPS ini dapat memberikan sumbangan bagi perkembangan psikologi sosial dan bermanfaat bagi pembaca.

\section{Salam}

Ketua Editor JPS

Bagus Takwin* 


\section{Daftar Pustaka}

Grasiaswaty, N., Widyartini, M. S., \& Siregar, R. E. (2019). Aku membelinya bukan karena aku suka: Bagaimana nilai (personal dan berbelanja) memengaruhi tendensi pembelian impulsif. Jurnal Psikologi Sosial, 17(1), 28-35. doi: $10.7454 /$ jps.2019.5

Hidayah, B., \& Hariyadi, S. (2019). "Siapa yang lebih terampil mengelola konflik rumah tangga?" Perbedaan manajemen konflik awal perkawinan berdasarkan gender. Jurnal Psikologi Sosial, 17(1), 12-20. doi: 10.7454/jps.2019.3

Jamil, R. A., Gunarya, A., \& Kusmarini, D. (2019). Ritual keluarga sebagai diskriminan keberfungsian keluarga. Jurnal Psikologi Sosial, 17(1), 46-56. doi: $10.7454 /$ jps.2019.7
Putra, A. D., Kusumawardhani, D. E., \& Nahertali, E. (2019). Teknik intervensi nudge dengan pendekatan norm untuk meningkatkan perilaku membaca remaja. Jurnal Psikologi Sosial, 17(1), 3-11. doi: $10.7454 /$ jps.2019.1

Sahrani, R. (2019). Faktor-faktor karakteristik kebijaksanaan menurut remaja. Jurnal Psikologi Sosial, 17(1), 36-45. doi: 10.7454/jps.2019.6

Widhyastuti, C., \& Ariyanto, A. (2019). "Peran moderasi kompetisi antar-kelompok dalam hubungan antara identifikasi kolektif dan ingroup criticism pada kelompok suporter sepakbola. Jurnal Psikologi Sosial, 17(1), 21-27. doi: $10.7454 /$ jps.2019.4 